\title{
Hydroxyurea for the Treatment of Recurrence and Unresectable Meningiomas: A Systematic Review
}

\author{
Dirga Rachmad Aprianto, Rahadian Indarto Susilo, Joni Wahyuhadi, Irwan Barlian Immadoel Haq* \\ Department of Neurosurgery, Dr. Soetomo Academic General Hospital, Faculty of Medicine, Airlangga University, Surabaya, \\ Indonesia
}

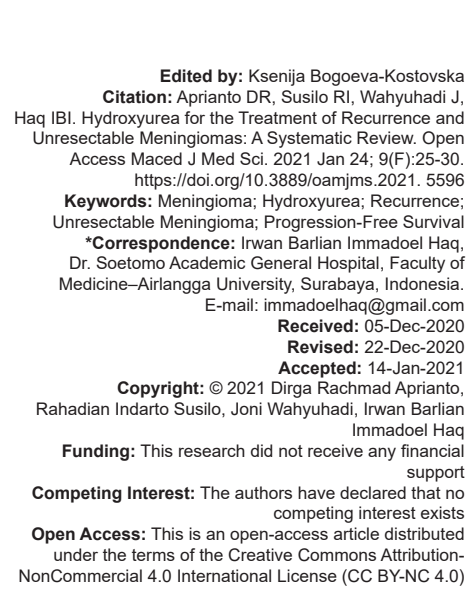

\section{Introduction}

Meningioma is the most common primary brain tumor, accounted for $\pm 35 \%$. It is estimated that 12 persons in a million have meningioma [1]. Meningioma is mostly benign (World Health Organization [WHO] Grade 1) and is often successfully treated with surgery [2], [3]. Surgery remains the best option in treating symptomatic or enlarging meningiomas where total removal of the tumor is the goal of surgery [4], [5]. However, in certain meningiomas due to its location, complete removal of the tumor is hard to achieve [6], [7]. Therefore, the degree of resection will increase the risk of post-surgical recurrence [8]. In some cases of patients with WHO Grade I meningioma where the tumor could not be totally resected, the tumor can transform to higher grade (atypical, WHO Grade II; anaplastic, WHO Grade III) ended with worse general outcomes and survival rate [3], [9].

Radiation therapy is now used as one of the treatment modalities in unresectable or recurrent meningiomas as well as in atypical or anaplastic meningiomas. Radiation therapy is shown to be effective to cease the growth of the tumor, but not in tumor regression [8]. An alternative treatment option as an adjuvant therapy for patients with recurrence or unresectable meningiomas is essential to improve the survival and clinical outcomes of these patients. Unfortunately, the uses of hormone therapy, immunotherapy, or chemotherapy had variable results and not consistently effective [8], [10]. Although only being reported in several small studies, hydroxyurea, a ribonucleotide reductase inhibitor, had promising results in patients with recurrence or unresectable meningiomas with radiographic response rates of $6 \%$ and med progression-free survival (PFS) of 44-176 weeks [10].

Hydroxyurea was previously known as a chemotherapy drug for chronic myelogenous leukemia and could be used for years with low or transient toxicity [8], [10]. Hydroxyurea is currently used in the treatment of myeloproliferative disorders, chronic 
myelogenous leukemia, and polycythemia rubra vera in particular [11], Hydroxyurea plays a role as a cell cycle-specific urea analog that discourages the enzyme ribonucleotide diphosphate reductase and interferes with deoxyribonucleic acid (DNA) synthesis by minimizing the available pool of DNA [11], [12]. The cytotoxic effects of hydroxyurea correlate with the dose or concentration achieved, as well as with the duration of drug exposure [12]. Hydroxyurea also has a more global inhibitory effect on the replitase complex of tumor cells [12]. Some prospective studies had been done in investigating the efficacy of hydroxyurea with promise result in patients with recurrence or unresectable meningioma; however, the data are still indeterminate [8], [13], [14]. Therefore, this study is conducted to analyze the efficacy and safety of hydroxyurea for the treatments of patients with recurrence or unresectable meningiomas.

\section{Materials and Methods}

\section{Information sources and search strategy}

This systematic review was conducted based on PRISMA guidelines. Studies were obtained by searching electronic databases, PUBMED, Cochrane, and JNS in August 2020. Studies that were included ranged from 2000 - 2012. Only were articles in Bahasa and English included. Authors used the following keywords searching to find out all trial registers and databases: "hydroxyurea" or "meningioma" or "recurrent" or "recurrence" and "unresectable." No ethical clearance was needed for this study.

\section{Eligibility criteria}

Study used was full-text observational study or randomized control trial (RCT) about hydroxyurea treatment in recurrent or unresectable meningioma. Reviews, unpublished articles, letter to editor, abstracts, and study not written in English or Bahasa were excluded from the study. Study characteristics are presented as PICO in Table 1.

Table 1: PICO of the study

\begin{tabular}{ll}
\hline Population & Adult aged 19-70, patient with recurrent or unresectable meningioma \\
Intervention & Hydroxyurea \\
Comparison & - \\
Outcome & PFS, safety \\
\hline PFS: Progression-free survival.
\end{tabular}

\section{Quality assessment}

The methodological quality in each of these studies was assessed using the risk-of-bias assessment tool based on the Cochrane Handbook for Systematic Reviews of Interventions (version 5.1.0) by two reviewers.

\section{Data collection and analysis}

\section{Selection of studies}

The search results were excluded based on the relevancy of both the titles and the abstracts. NonEnglish/non-Bahasa publications were automatically excluded. Full-text articles were then assessed by all authors for potentially eligible RCTs. The reasons of exclusion were noted and reported. Included studies are represented in Table 2.

\section{Results}

\section{Literature search}

A flow diagram of study selection is shown in Figure 1. After initially identifying 425 articles, 212 were excluded and the full texts of 213 were reviewed. Subsequently, 207 studies were excluded, and 6 studies were included in the systematic review (Table 2).

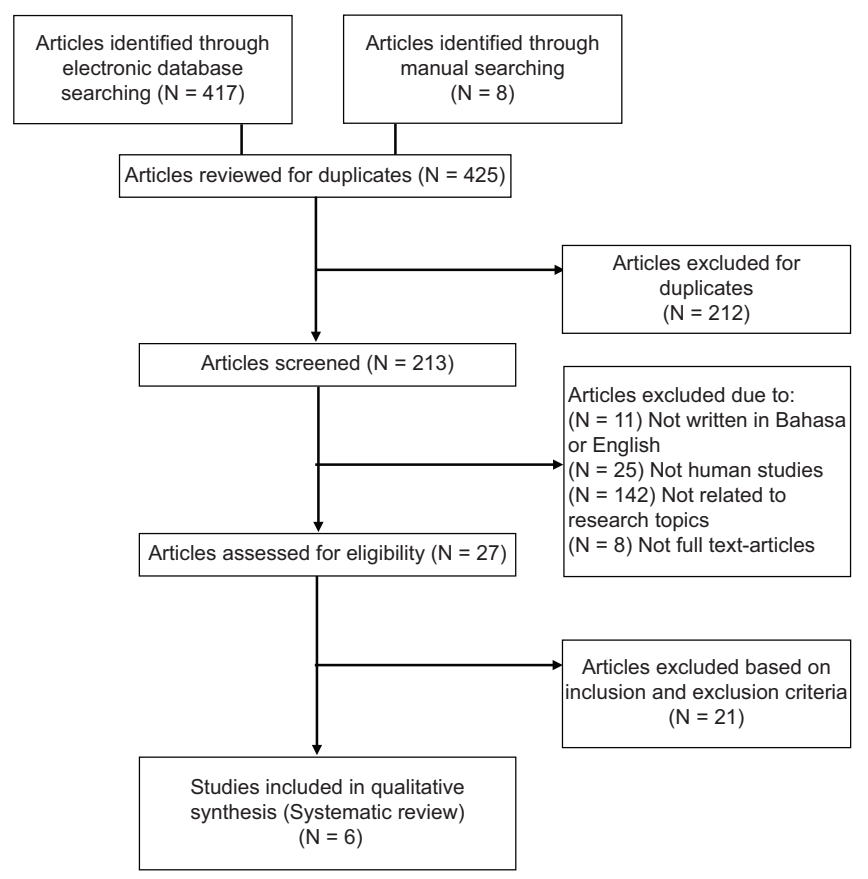

Figure 1: Study flowchart

\section{Pre-treatments}

There were six studies with total of 157 meningioma patients in this review. Among participants, 153 out of 157 patients (97.45\%) had undergone surgery and 82 patients had undergone surgery more than once. In all, 117 patients $(74.5 \%)$ had previously been treated with fractioned radiotherapy (total dose ranged from 50.4 to $61.2 \mathrm{~Gy}$ ) and 91 patients $(57.9 \%)$ were in addition treated with stereotactic radiotherapy (dose ranged from 12 to $18 \mathrm{~Gy}$ ). 
Table 2: Hydroxyurea study data

\begin{tabular}{|c|c|c|c|c|c|c|c|c|c|}
\hline Author & Year & Type of study & Patients & $\begin{array}{l}\text { History surgery } \\
\text { TR/STR/Bio/No }\end{array}$ & $\begin{array}{l}\text { Average Age/ } \\
\text { Range }\end{array}$ & $\begin{array}{l}\text { Grades I/II/ } \\
\text { III/NS }\end{array}$ & $\begin{array}{l}\text { Treatment } \\
\text { dose }\end{array}$ & Outcomes & AEs \\
\hline Newton et al. [13] & 2000 & PS & 17 & $\begin{array}{l}13 \text { patients, NS; } 6 \\
\text { patients more than } 1\end{array}$ & $\begin{array}{l}57.2 \\
33-74\end{array}$ & $13 /-/ / / 4$ & $\begin{array}{l}\mathrm{HU} 20 \\
\mathrm{mg} / \mathrm{kg} / \mathrm{d}\end{array}$ & $\begin{array}{l}14 \text { out of } 16 \text { ( } 88 \% \text { ) SD, PFS } \\
5-36 \text { mo, med PFS } 20 \text { mo } \\
\text { Grd I } 10 \text { SD, PFS } 2.5-36 \\
\text { mo; } 1 \text { ex } \\
\text { NS } 4 \text { SD, PFS } 14-36 \text { mo }\end{array}$ & $\begin{array}{l}\text { Hematological } 11(65 \%, \\
\text { grd III/IV 5) } \\
\text { Uric acid } 2(12 \%) \\
\text { Fatigue } 2(12 \%)\end{array}$ \\
\hline Mason et al. [8] & 2002 & PS & 20 & $\begin{array}{l}\text { All had surgery, NS; } \\
14 \text { patients more } \\
\text { than } 1\end{array}$ & $\begin{array}{l}59 \\
31-75\end{array}$ & 16/3/1/- & $\begin{array}{l}\mathrm{HU} 20-30 \\
\mathrm{mg} / \mathrm{kg} / \mathrm{d}\end{array}$ & $\begin{array}{l}65 \% \text { SD, PFS } 2-38 \mathrm{mo} \text {, med } \\
\text { PFS } 30,5 \text { mo } \\
\text { Grd I } 12 \text { SD } 1 \text { mPR, PFS } \\
2-38 \text { mo } \\
\text { Grd II } 1 \text { SD PFS } 3-11.25 \mathrm{mo} \\
\text { Gr III } 0 \text { SD, PFS } 1 \text { mo }\end{array}$ & $\begin{array}{l}\text { Hematological } 8(40 \% \text {; grd III } 3) \\
\text { Hepatic } 1(5 \%)\end{array}$ \\
\hline Loven et al. [14] & 2004 & PS & 12 & $\begin{array}{l}\text { All had surgery, NS; } \\
10 \text { patients more } \\
\text { than } 1\end{array}$ & $\begin{array}{l}56.9 \\
41-77\end{array}$ & 8/4/-/- & $\begin{array}{l}\mathrm{HU} 20 \\
\mathrm{mg} / \mathrm{kg} / \mathrm{d}\end{array}$ & $\begin{array}{l}1 \text { out of } 10(10 \%) \text { SD-mPR, } \\
\text { PFS } 4 \text { - } 24 \text { mo } \\
\text { Grd I } 1 \text { SD-mPR, PFS 4-24 } \\
\text { mo, } 1 \text { ex } \\
\text { Grd II } 0 \text { SD, PFS 9-13 } \\
\text { mo, } 1 \text { ex }\end{array}$ & $\begin{array}{l}\text { Convulsion } 1(8.3 \%) \\
\text { Hematological } 4 \\
\text { (33.3\%; grd III/IV 4) } \\
\text { Cutaneous } 1(8.3 \%) \\
\text { Hepatologic } 1(8.3 \%)\end{array}$ \\
\hline $\begin{array}{l}\text { Chamberlain and } \\
\text { Johnston [15] }\end{array}$ & 2011 & RS & 60 & $\begin{array}{l}20 / 31 / 9 /- \\
29 \text { patients more } \\
\text { than } 1\end{array}$ & $\begin{array}{l}61.5 \\
26-88\end{array}$ & $60 /-/-/-$ & $\begin{array}{l}1000 \mathrm{mg} / \\
\mathrm{m}^{2} / \mathrm{d}\end{array}$ & 35\% SD; PFS 3-12 mo & $\begin{array}{l}\text { Hematological } 20(33 \%) \\
\text { Fatigue } 15(25 \%) \\
\text { GIT } 10(16.7 \%) \\
\text { Infection } 2(3.3 \%) \\
\text { Thrombophlebitis } 3(5 \%)\end{array}$ \\
\hline Chamberlain [16] & 2012 & RS & 35 & $\begin{array}{l}17 / 13 / 5 /- \\
21 \text { patients more } \\
\text { than } 1\end{array}$ & $\begin{array}{l}63 \\
34-86\end{array}$ & $-/ 22 / 13 /-$ & $\begin{array}{l}\mathrm{HU} 1000 \\
\mathrm{mg} / \mathrm{m}^{2} / \mathrm{d}\end{array}$ & $\begin{array}{l}43 \% \text { SD, PFS } 0.5-7 \mathrm{mo}, \\
\text { med PFS } 2 \text { mo }\end{array}$ & $\begin{array}{l}\text { Anemia } 5(14.28 \% \text {, grd III } 1) \\
\text { Fatigue } 12(34.28 \% \text {, grd III } 2) \\
\text { Neutropenia } 3(8.57 \%) \\
\text { Lymphopenia } 5(14.28 \%) \\
\text { GIT } 8(22.85 \%) \\
\text { Infection } 2(5.71 \%) \\
\text { Thrombophlebitis } 2(5.71 \%)\end{array}$ \\
\hline Kim [11] & 2012 & RS & 13 & $\begin{array}{l}\text { All had surgery, NS; } 2 \\
\text { patients more than } 1 \\
1 /-/-/-\end{array}$ & $32-83$ & 8/5/-/- & $\begin{array}{l}\mathrm{HU} 1000 \\
\mathrm{mg} / \mathrm{m}^{2} / \mathrm{d}\end{array}$ & $\begin{array}{l}\text { Gr I/II } 10 \text { SD, PFS 8-128 } \\
\text { mo, med PFS } 72.4 \text { mo }\end{array}$ & $\begin{array}{l}\text { Persisting hematologic } \\
\text { manifestation } 1(7.6 \%)\end{array}$ \\
\hline
\end{tabular}

\section{Hydroxyurea dosage}

The schedule of hydroxyurea administration applied in the six studies was similar in which hydroxyurea was administered orally for 28 consecutive days (defined as a cycle of therapy) and repeated every 28 days or after the recovery from adverse events (AEs) acquired in previous cycle. The dosage of hydroxyurea was varied in six of studies. Hydroxyurea was administered at a dose of $20-30 \mathrm{mg} / \mathrm{kg}$ divided twice per day in three studies and $1000 \mathrm{mg} / \mathrm{m}^{2}$ per day in two studies.

\section{Histopathology grading}

It is essential to consider the grades of the tumor in evaluating the tumor responses to hydroxyurea, its effect might be different for different grade of the tumor. In a study reported by Newton et al., the histological feature of tumor from 17 patients was $13(76.47 \%)$ with Grade I meningioma and 4 (23.53\%) with no histopathological confirmation (not operated). In another study reported by Mason et al., a prospective study, histological features reported from 20 patients include $16(80 \%)$ subjects with Grade I meningioma, $3(15 \%)$ with Grade II meningioma, and 1 (5\%) with Grade III meningioma. Other prospective studies had been conducted to determine the effect of hydroxyurea in different grades of the tumors. Loven et al. included 12 patients: $8(66.67 \%)$ had Grade I meningioma and $4(33.33 \%)$ had Grade 2 meningioma. Meanwhile, other two different retrospective studies including larger number of meningioma patients had been reported by
Chamberlain and Chamberlain-Johnston with total of 95 patients: 60 (63.15\%) had Grade I meningioma, 22 $(23.16 \%)$ had Grade II meningioma, and 13 (13,69\%) had Grade III meningioma.

\section{Effectiveness of hydroxyurea}

This study included total 105 cases of Grade I meningioma, 48 cases of Grades II and III, and 4 cases with no histopathological confirmation. PFS was used to determine the effectiveness of hydroxyurea in different grades of the tumors. PFS was defined as the time from the $1^{\text {st }}$ day of treatment with hydroxyurea until initial disease progression. Patient with Grade I meningioma which as many as 54 out of $105(51 \%)$ had stable disease (SD) with the shortest PFS of 2 months and the longest PFS of 128 months. For high-grade meningioma (Grades II and III) with total of 48 patients, the PFS ranged from 0,5 - 13 months. Meanwhile, four patients without histopathological confirmation, all of 8 patients had SD $(100 \%)$ with PFS ranging from 10 to 36 months.

\section{Dose and outcome}

According to the treatment doses compared to the outcomes, it is implied that the intervention using hydroxyurea $20-30 \mathrm{mg} / \mathrm{kg} / \mathrm{d}$ was associated with prolonged PFS (2-38 months) in Grade I compared to Grade II with shorter PFS (3-11.25 months). Besides, there were 12 SDs represented in Grade I, surpassing SD alone observed in Grade II. Another study used 20 
$\mathrm{mg} / \mathrm{kg} / \mathrm{d}$ only for both Grades I and II group. The result was surprisingly consistent with the previous one in which there was prolonged PFS (4-24 months) in Grade I group and shorter PFS (9-13 months) in Grade II group. The SD number did not show any differences among both groups. Thus, hydroxyurea administration with dose ranging from 20 to $30 \mathrm{mg} / \mathrm{kg} / \mathrm{d}$ was considered as the suitable dose and more effectively for Grade I class.

\section{Adverse effect}

Overall, the majority of patients tolerated the dosage of hydroxyurea used in these series with minimal complications. Hematological $A E$ was the most common $\mathrm{AE}$ with frequency range 33-65\% followed by other AEs. Fatigue was in the second place with frequency range $12-34.28 \%$. Meanwhile, there were also certain AEs with lesser frequency range (5-33.33\%) such as GIT, hepatic, Iymphopenia, and cutaneous manifestation. One severe manifestation was a convulsion (8.3\%) reported by Loven et al. [14] Most studies had limitation and did not explain whether the adverse effect occurred in the same subject or not.

\section{Discussion}

In general, administration of hydroxyurea to the patients in the six studies above showed sufficiently good results. The result presented a varied SD rate, ranging from 30 to $69 \%$ (>60\% in three studies) with a med PFS varying between 2 and 27.75 months. The level of safety and tolerance is also rather advanced in which all studies found only two major pathological responses to hydroxyurea administration. In addition, the most common side effects are hematological disorders (anemia, thrombocytopenia, and leukopenia) which range from 20 to $65 \%$ [8], [9], [13], [14], [15], [16].

The mechanism of hydroxyurea therapy administration to patients in the six studies above was not much different. All studies performed oral hydroxyurea administration at a dose of $20-30 \mathrm{mg} / \mathrm{kg}$ body weight/ day or $1000 \mathrm{mg} / \mathrm{m} 2 /$ day [8], [13], [14], [15], [16]. Based on the experience of the study by Grabenbauer et al. in 2002, glioblastoma patients were given infusion topotecan and accelerated hyper fractionated $3 d$-conformal radiation [17]. However, the results of this different regimen were not different from other studies, where in this study the SD rate was around $66 \%$ and med PFS ranged from 13 months (Grade II/ III meningioma) to 20 months (Grade I meningioma). Similarly, the AEs rate was not much different from other studies [8], [9], [13], [14], [15], [16]. Mason et al. [8] revealed that there was about $75 \%$ SD in Grade I (12 of 16 patients) while Grade II/III had higher percentage (25\% SD in 1 of 4 patients). Similar results were presented by
Newton et al., discovering 76\% SD in Grade I. In other studies, the SD rates between Grade I and Grade II/III meningiomas in each study were not different. This is consistent with the previous studies which show that the use of hydroxyurea is more intended to prevent the progression of high-grade meningioma, not to achieve a complete or partial response [18], [19].

However, med PFS in the above studies showed some differences. The response rate to hydroxyurea in all studies was very low, with only two patients from all studies showing minimal response, and the rest showing SD or PD [8], [9], [13], [14], [15], [16]. A recent study by Chamberlain et al., 2011 and 2012, showed that the med PFS in all patients with Grade II/III was only 2 months [15], [16]. Whereas in another study, there was a difference in med PFS between patients with Grade I and Grade II/III meningiomas with med PFS ranging from 13 to 22.77 months for Grade I meningiomas and 1-27.75 months for Grade II/III meningiomas. This is most likely due to different follow-up methods in the more stringent Chamberlain study in which a complete neurological examination was performed every 4 weeks and an magnetic resonance imaging (MRI) examination every 8 weeks. Meanwhile, other studies only performed follow-up MRI/computed tomography scans and complete neurological examinations every 12-16 weeks. This may also be due to the improvement of MRI imaging technologies, considering that the time distance between Chamberlain's study and other studies was 6-12 years and the Chamberlain study performed follow-up imaging with $\mathrm{MRI}$ alone in all patients [8], [9], [13], [14], [15], [16], [20], [21].

The progressive rate in the six studies can be seen from the SD rate where the SD rate ranged from 30 to $69 \%$ but the average study found that the SD rate is above $60 \%$ (three studies) [8], [9], [13], [15], [16]. Another difference between the SD rate of Grade I and Grade II/III meningiomas can be seen in the Chamberlain study where in 60 patients with Grade I meningiomas, the SD rate is $35 \%$ while in 35 patients with Grade II/III meningiomas, the SD rate is $43 \%$ [15], [16].

Patient tolerance to hydroxyurea was high in that in all studies there were only two major pathological responses (both in Grade 1 meningioma). AEs that appear also, based on literature, are not much different from other chemotherapy administration in which in this study, the most frequent AEs were hematological $A E$ with hematological Grade $A E$ I and II [8], [9], [13], [14], [15], [16], [19].

Concurrently, if AEs appeared in Grade III patients, the samples were excluded except those emerged in Grade II patients. This was due to the shorter PFS observed in Grade III patient which presented meaningless outcome [8]. In addition, although hydroxyurea has some advantages particularly related to safety effects, it is considered that the treatment for Grade III may not able to be administered for favorable outcomes. 
Overall, the use of hydroxyurea showed good outcomes, regardless of achieving partial or complete responses. Further investigation studies of hydroxyurea in combination with other modality treatments, such as radiation and bevacizumab, are essential to explore the use of hydroxyurea in treating meningioma. Bevacizumab is also well-tolerated and active against recurrent malignant gliomas [22], [23]. In addition, important advantages of bevacizumab are its ability to decrease peritumoral edema and function as a corticosteroid-sparing agent [22]. Moreover, study from Hahn et al. [9] using both hydroxyurea and radiotherapy demonstrated an increasing PFS among 21 patients with meningioma, compared to those who were given radiotherapy only. Thus, it is needed to consider the combination therapy with either bevacizumab or radiotherapy which also offered encouraging efficacy and safety results in managing patients with meningioma [24], [25].

\section{Conclusion}

Patients with unresected and recurrent meningiomas currently have limited treatment options due to the difficulty for surgical management. This study offers another perspective addressing the efficacy and safety results with the use of hydroxyurea. In our review, hydroxyurea showed good result in preventing tumor progression, particularly in Grade 1 meningioma. Although the efficacy and safety are still inconclusive due to limited studies, AEs in meningioma patients treated with hydroxyurea are relatively low. Further combination treatment may be used as a multimodal therapy.

\section{References}

1. Ostrom QT, Gittleman H, Farah $P$, Ondracek A, Chen $Y$, Wolinsky $Y$, et al. CBTRUS statistical report: Primary brain and central nervous system tumors diagnosed in the United States in 2006-2010. Neuro Oncol. 2013;15 (Suppl 2):ii1-56. https:// doi.org/10.1093/neuonc/not151

PMid:24137015

2. Engelhard $H H$, Villano JL, Porter KR, Stewart AK, Barua M, Barker FG, et al. Clinical presentation, histology, and treatment in 430 patients with primary tumors of the spinal cord, spinal meninges, or cauda equina. J Neurosurg Spine. 2010;13(1):6777. https://doi.org/10.3171/2010.3.spine09430

PMid:20594020

3. Al-Mefty O, Kadri PA, Pravdenkova S, Sawyer JR, Stangeby C, Husain M. Malignant progression in meningioma: Documentation of a series and analysis of cytogenetic findings. J Neurosurg. 2004;101(2):210-8. https://doi.org/10.3171/ jns.2004.101.2.0210

\section{PMid:15309910}

4. Apra C, Peyre M, Kalamarides M. Current treatment options for meningioma. Expert Rev Neurother. 2018;18(3):241-9. https:// doi.org/10.1080/14737175.2018.1429920

PMid:29338455

5. Rogers L, Barani I, Chamberlain M, Kaley TJ, McDermott M Raizer $\mathrm{J}$, et al. Meningiomas: Knowledge base, treatment outcomes, and uncertainties. A RANO review. J Neurosurg. 2015;122(1):4-23. https://doi.org/10.3171/2014.7.jns131644 PMid:25343186

6. Grunberg SM, Weiss MH, Spitz IM, Ahmadi J, Sadun A, Russel CA, et al. Treatment of unresectable meningiomas with the antiprogesterone agent mifepristone. J Neurosurg. 1991;74(6):861-6. https://doi.org/10.3171/jns.1991.74.6.0861 PMid:2033444

7. Ortolá Buigues $A$, Crespo Hernández I, Jorquera Moya M, Díaz Pérez JÁ. Unresectable recurrent multiple meningioma: A case report with radiological response to somatostatin analogues. Case Rep Oncol. 2016;9(2):520-5. https://doi. org/10.1159/000448212

PMid:27721778

8. Mason WP, Gentili F, MacDonald DR, Hariharan S, Cruz CR, Abrey LE. Stabilization of disease progression by hydroxyurea in patients with recurrent or unresectable meningioma. J Neurosurg. 2002;97(2):341-6. https://doi.org/10.3171/ jns.2002.97.2.0341

PMid:12186462

9. Hahn BM, Schrell UM, Sauer R, Fahlbusch R, Ganslandt O, Grabenbauer GG. Prolonged oral hydroxyurea and concurrent $3 \mathrm{~d}$-conformal radiation in patients with progressive or recurrent meningioma: Results of a pilot study. J Neurooncol. 2005;74(2):157-65. https://doi.org/10.1007/s11060-004-2337-3 PMid:16193387

10. Reardon DA, Norden AD, Desjardins A, Vredenburgh JJ, Herndon JE, Coan A, et al. Phase II study of Gleevec® plus hydroxyurea $(\mathrm{HU})$ in adults with progressive or recurrent meningioma. J Neurooncol. 2012;106(2):409-15. https://doi. org/10.1007/s11060-011-0687-1

PMid:21938530

11. Kim MS, Yu DW, Jung YJ, Kim SW, Chang CH, Kim OL. Longterm follow-up result of hydroxyurea chemotherapy for recurrent meningiomas. J Korean Neurosurg Soc. 2012;52(6):517-22. https://doi.org/10.3340/jkns.2012.52.6.517 PMid:23346322

12. Newton HB. Hydroxyurea chemotherapy in the treatment of meningiomas. Neurosurg Focus. 2007;23(4):E11.

PMid:17961035

13. Newton HB, Slivka MA, Stevens C. Hydroxyurea chemotherapy for unresectable or residual meningioma. J Neurooncol. 2000;49(2):165-70.

PMid: 11206012

14. Loven D, Hardoff R, Sever ZB, Steinmetz AP, Gornish M, Rappaport ZH, et al. Non-resectable slow-growing meningiomas treated by hydroxyurea. J Neurooncol. 2004;67(1-2):221-6. https://doi.org/10.1023/b:neon.0000021827.85754.8e PMid:15072471

15. Chamberlain MC, Johnston SK. Hydroxyurea for recurrent surgery and radiation refractory meningioma: A retrospective case series. J Neurooncol. 2011;104(3):765-71. https://doi. org/10.1007/s11060-011-0541-5 PMid:21318318

16. Chamberlain MC. Hydroxyurea for recurrent surgery and radiation refractory high-grade meningioma. J Neurooncol. 2012;107(2):315-21. https://doi.org/10.1007/s11060-011-0741-z 


\section{PMid:22127733}

17. Grabenbauer GG, Anders K, Fietkau RJ, Klautke G Feldmann HJ, Weiser S, et al. Prolonged infusional topotecan and accelerated hyperfractionated $3 \mathrm{~d}$-conformal radiation in patients with newly diagnosed glioblastoma--a phase I study. J Neurooncol. 2002;60(3):269-75.

PMid:12510778

18. Kim J, Kim KH, Kim YZ. The clinical outcome of hydroxyurea chemotherapy after incomplete resection of atypical meningiomas. Brain Tumor Res Treat. 2017;5(2):77-86. https:// doi.org/10.14791/btrt.2017.5.2.77

PMid:29188208

19. Moazzam AA, Wagle N, Zada G. Recent developments in chemotherapy for meningiomas: A review. Neurosurg Focus. 2013;35(6):1-10. https://doi.org/10.3171/2013.10.focus13341

20. Lohrke J, Frenzel T, Endrikat J, Alves FC, Grist TM, Law M, et al. 25 years of contrast-enhanced MRI: Developments, current challenges and future perspectives. Adv Ther. 2016;33(1):1-28. https://doi.org/10.1007/s12325-015-0275-4

PMid:26809251

21. Sobol WT. Recent advances in MRI technology: Implications for image quality and patient safety. Saudi J Ophthalmol.
2012;26(4):393-9. https://doi.org/10.1016/j.sjopt.2012.07.005 PMid:23961024

22. Norden AD, Young GS, Setayesh K, Muzikansky A, Ciampa AS, Ebbeling LG, et al. Bevacizumab for recurrent malignant gliomas: Efficacy, toxicity, and patterns of recurrence. Neurology. 2008;70(10):779-87. https://doi.org/10.1212/01. wnl.0000304121.57857.38

PMid:18316689

23. Chamberlain MC. Bevacizumab for the treatment of recurrent glioblastoma. In: Clinical Medicine Insights: Oncology. Vol. 5. New Zealand: Libertas Academica Ltd.; 2011. p. 117-29.

24. Lou E, Sumrall AL, Turner S, Peters KB, Desjardins A, Vredenburgh $\mathrm{JJ}$, et al. Bevacizumab therapy for adults with recurrent/progressive meningioma: $A$ retrospective series. J Neurooncol. 2012;109(1):63-70. https://doi.org/10.1007/ s11060-012-0861-0

PMid:22535433

25. Mitra S, Li G, Harsh GR $4^{\text {th }}$. Passive antibody-mediated immunotherapy for the treatment of malignant gliomas. Neurosurg Clin N Am. 2010;21(1):67-76. https://doi. org/10.1016/j.nec.2009.08.010

PMid:19944967 